\title{
Phagocytosis Induced by Yeast Cells in Canine Granulocytes: A Methodological Study
}

\author{
By Gunilla Trowald-Wigh and Kerstin Thorén-Tolling
}

Department of Medicine and Surgery, Veterinary Faculty, Swedish University of Agricultural Sciences, Uppsala, Sweden.

\begin{abstract}
Trowald-Wigh, G., K. Thorén-Tolling: Phagocytosis induced by yeast cells in canine granulocytes: A methodological study. Acta vet. scand. 1990, 31, 87-95. - A phagocytic function assay of canine granulocytes was established. This method allows the proportion of active granulocytes to be estimated as well as the number of adhered and ingested yeast cells. The influence of different factors on phagocytosis was studied. Temperature variation within the interval $36-41^{\circ} \mathrm{C}$ did not affect phagocytosis. The incubation time for optimal phagocytosis of yeast cells was 35 min. The opsonization procedure giving the optimal phagocytosis was purified IgG and serum together.

neutrophil; dog; ingestion; adherence; active granulocytes; temperature; opsonization.
\end{abstract}

\section{Introduction}

Phagocytosis is considered to be an important defense mechanism for preserving the integrity of organisms. The neutrophil granulocyte is an important and efficient phagocyte and plays a key role in the defense mechanism against invading microorganisms. In man, a number of disorders with impaired phagocytosis have been described, where those suffering from the condition are characterized by enhanced susceptibility to pyogenic infections (Stossel 1974, Klebanoff \& Clark 1978, Hảkansson \& Venge 1980).

Microbicidal defects associated with impairment of oxidative metabolism have been demonstrated in connection with chronic granulomatous disease in man (Holmes et al. 1967), and disturbances in different stages of the ingestion and phagocytic procedure have been described in e.g. autoimmune diseases and in connection with uremia (Hällgren et al. 1978, 1979).
Only limited information is available on the frequency of comparable disorders in the neutrophil function in dogs. Kroese et al. (1981) investigated chemotaxis and intracellular killing in dogs with recurrent infections and did not detect any impaired functions in the granulocytes. Other authors have described dysfunctions of intracellular killing (Renshaw et al. 1975, 1977, Chusid et al. 1975 ) as well as impaired chemotaxis (Bowles et al. 1979) in canine neutrophil granulocytes. Morrison et al. (1987) reported defective migration in connection with primary ciliary dyskinesia. Gosset et al. (1984) studied neutrophil function during experimental inflammatory disease in dogs and the results indicate that a defect in bactericidal activity can occur in dogs with inflammatory disease.

Many different methods for studying phagocytic mechanisms have been reported. A kinetic technique for evaluation of the inge- 
stion of Latex particles into human granulocytes has been described by Hällgren et al. (1977). Phagocytosis and intracellular killing of live bacteria in canine granulocytes was studied by Renshaw et al. (1977), using a model for evaluation of viability of bacteria after ingestion. Hed (1977) described an end point technique on human granulocytes with fluorescein conjugated yeast cells, where the number of ingested as well as adhered yeast cells could be evaluated separately.

The aim of our study was to establish a phagocytic function assay, suitable for canine neutrophils, with which one can assess ingestion separately, adherence separately and also the proportion of granulocytes, able to ingest or adhere.

\section{Materials and methods \\ Experimental animals}

Blood from 46 healthy dogs, 24 females and 22 males, age 1-11 years (mean age 4.2 years) was used for studies of granulocytic phagocytosis. Four breeds were represented: german shepherd $(n=8)$, labrador retriever $(n=15)$, boxer $(n=9)$ and beagle $(n=14)$.

\section{Blood samples}

Ten ml blood was collected from the cephalic vein into heparinized tubes (Vacutainer system, Becton Dickinson, Meylan, France) for isolation of granulocytes and $5 \mathrm{ml}$ in EDTA tubes, (Vacutainer system, Becton Dickinson) for determination of hemoglobin (Hb), red blood cells (RBC), white blood cells (WBC) and differential leucocyte count.

\section{Isolation of granulocytes}

Five $\mathrm{ml}$ whole blood was mixed with an equal volume dextran solution: Dextran (20 g/l) (T-500, Pharmacia Fine Chemicals, Uppsala, Sweden) diluted in physiological saline $(9 \mathrm{~g} \mathrm{NaCl} / 1)$. The erythrocytes were allowed to sediment for $30 \mathrm{~min}$ at room temperature. The supernatant, containing the leucocytes, was collected and centrifuged (150xg) for $5 \mathrm{~min}$. The pellet was suspended in Ringerdex (Travenol laboratorier, A/S Halden Norway) and centrifuged as above. This washing procedure was repeated and subsequently, the cells were suspended in Ringerdex. The remaining erythrocytes were hemolyzed with hypotonic saline for $30 \mathrm{sec}$ and finally the cells were suspended in Ringerdex-glucose. Just before use the cells were diluted in Ringerdex-glucose to a concentration of $6 \times 10^{8}$ cells/l. The final cell suspension contained $75 \%$ neutrophil granulocytes. Basophilic granulocytes, monocytes, eosinophiles and mononuclear cells constituted the remaining $25 \%$.

Preparation of FITC conjugated yeast cells Saccharomyces cerevisiae (baker's yeast) was boiled in a water bath $\left(100^{\circ} \mathrm{C}\right)$ for 30 min. The solution was strained through gauze and washed twice in phosphate buffered saline (PBS) (pH 7.3, $40.2 \mathrm{mM}$ $\mathrm{Na}_{2} \mathrm{HPO}_{4}, \quad 9.8 \mathrm{mM} \mathrm{KH}_{2} \mathrm{PO}_{4}, 100 \mathrm{mM}$ $\mathrm{NaCl}$ ).

The heat-killed yeast cells $\left(4 \times 10^{11 / 1)}\right.$ were labeled with fluorescein isothiocyanate, FITC (Kebo Grave, 16391 Spånga, Sweden) in a carbonate buffer $(\mathrm{pH} 10,50 \mathrm{mM}$ $\mathrm{NaHCO}_{3}, 50 \mathrm{mM} \mathrm{Na} \mathrm{CO}_{3}$ ), $0.25 \mathrm{~g}$ FITC per litre buffer. The yeast cells were washed twice in PBS. The FITC-conjugated yeast cells were stored frozen at $-20^{\circ} \mathrm{C},\left(10^{13}\right.$ yeast cells/l).

\section{Preparation of Trypan blue solution}

Trypan blue ( $25 \mathrm{~g} / \mathrm{l})$ (Kebo Grave), was solved in a mixture of one part citrate-phospha-

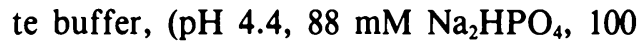
$\left.\mathrm{mM} \mathrm{C}_{6} \mathrm{H}_{8} \mathrm{O}_{7}\right)$ and 3 parts of saline $(9 \mathrm{~g} / \mathrm{l})$. 
Preparation of rabbit anti yeast IgG

Rabbits were injected intramusculary with heat-killed Saccharomyces cerevisiae once a week for 5 weeks and then boostered once a month for 3 months. The yeast suspension $(0.3 \mathrm{ml})$ contained $3 \times 10^{10}$ particles $/ 1$ and was mixed with Freund's complete adjuvant $(0.5 \mathrm{ml})$ before injection.

The IgG fraction of the rabbit antiserum was fractionated by precipitation with ammonium sulphate. The precipitate was dialyzed in a cellophane tube in physiological saline ( $\mathrm{pH}$ 7.2) for 24 hours. The IgG fraction was diluted in physiological saline to a concentration of $8 \mathrm{~g} / \mathrm{l}$. The titre for an appropriate opsonization of the yeast particles (no agglutination between yeast particles but adequate amounts of IgG on the surface of the yeast cells) was estimated using FITC conjugated sheep-antirabbit-IgG antibodies (Axel Johnson instrument $\mathrm{AB}$, Solna, Sweden). The antibodies were used in 3 dilutions for the titration and incubated with yeast cells for 30 $\min$ at $37^{\circ} \mathrm{C}$. The appropiate concentration of antibodies binding to the yeast particles used in this study was $0.16 \mathrm{~g}$ protein $/ \mathrm{l}$.

\section{Preparation of yeast $\operatorname{IgG}$ and yeast $C 3 b$}

Rabbit anti-yeast IgG, diluted in KRG (Krebs Ringer phosphate buffer) was mixed with yeast cells $\left(5 \times 10^{10} / 1\right)$ in equal parts. After incubation at $37^{\circ} \mathrm{C}$ for $30 \mathrm{~min}$, the opsonized yeast cells were washed twice in distilled water and diluted to $3 \times 10^{9} / 1$ in $\mathrm{KRG}$, pH 7.3.

To yield yeast $\mathrm{C} 3 \mathrm{~b}$, equal parts of pooled normal dog serum (NDS), diluted in PBS to $50 \%$ and yeast cells, $5 \times 10^{10}$ cells $/ 1$ in $\mathrm{KRG}$, were mixed and incubated for $30 \mathrm{~min}$ at $37^{\circ} \mathrm{C}$. After an additional wash in KRG buffer, the yeast cells were resuspended in KRG buffer to the cell concentration of $3 \times 10^{9} / 1$. Yeast cells were also coated with both IgG and $\mathrm{C} 3 \mathrm{~b}$; cells, $5 \times 10^{10} / 1$ were mixed with anti-yeast IgG, $0.16 \mathrm{~g} / 1$, diluted in $\mathrm{KRG}$ and pooled canine serum $(50 \%)$ in equal parts. After incubation at $37^{\circ} \mathrm{C}$ for $30 \mathrm{~min}$, the opsonized yeast cells were washed twice in distilled water and diluted to $3 \times 10^{9}$ cells $/ 1$ in KRG buffer.

\section{Assay of phagocytic activity}

The granulocyte solution containing $6 \times 10^{8}$ cells/l was added to 2 spots $(0.1 \mathrm{ml}$ each $)$ of a 3 spot glass slide (Microprint slides Laboratory design AB, Stockholm, Sweden) with a spot diameter of $14 \mathrm{~mm}$.

The neutrophils were allowed to adhere to the glass surface during a $30 \mathrm{~min}$ incubation in $39^{\circ} \mathrm{C}$ in a moistened chamber. The suspension was rinsed off in warm KRG and $0.1 \mathrm{ml}$ of yeast cell suspension was added. After the incubation time the yeast suspension was poured off and the phagocytosis was interrupted in ice cold KRG. Three drops of Trypan blue solution were added to each spot and poured off after a few seconds. The slides were examined immediately after addition of the dye in a Zeiss incident light microscope provided with phase contrast. The adhered yeast cells were stained by the Trypan blue and lost their fluorescence. The ingested yeast cells remained fluorescent since the dye did not pass through the cell wall in viable granulocytic cells (Hed 1977). The viability of the granulocytes was evaluated by Trypan blue staining of the prepared glass slides and thus, cells stained by this dye reagent were not included in the counting of granulocytes.

The results were expressed as: 1 . the number of active granulocytes per 100 granulocytes $=$ cells that have ingested and/or had particles attached to the surface, 2 . the number of ingested yeast cells per 100 granulocytes and 3. the number of adhered yeast cells per 100 granulocytes. 


\section{Sensitivity of the method}

The number of active granulocytes as well as ingested and adhered yeast cells were determined in duplicate, both on the same and on different slides, on blood samples from 9 dogs. Phagocytosis was interrupted after 35 min and the yeast cells were opsonized with both serum and IgG.

\section{Statistics}

Statistical analysis of the study of temperature and opsonization was performed with Student's t-test on paired observations with SAS (Statistical Analysis System).

The error of estimation was calculated as the coefficient of variation (CV) from duplicate samples according to the formula $s=\sqrt{\frac{2 \mathrm{~d} 2}{2 \mathrm{n}}}$

Statistical analysis of the kinetic study was performed within each group by analysis of variance using the General Linear Model procedure (SAS Institute Inc. 1985).

The statistical model included the effect of animal and the effect of incubation time.

Levels of significance are expressed conventionally:

ns not significant

* $\mathrm{p}<0.05$

** $\mathrm{p}<0.01$

$* * * 0<0.001$

Results in figures and tables are presented as means \pm s.e.m. unless otherwhise stated.

\section{Results}

\section{The influence of temperature}

The influence of different temperatures on the number of activated granulocytes and in- gested or adhered yeast cells was studied $(n=6)$. Samples from the same dog were incubated with yeast cells simultaneously in $36-37^{\circ}, 38-39^{\circ}$ and $40-41^{\circ}$ in 3 different incubators. Phagocytosis was interrupted after $25 \mathrm{~min}$. No differences related to varying temperatures could be detected (Table 1).

\section{The influence of opsonization}

In order to study the effect of serum opsonization $(\mathrm{C} 3 \mathrm{~b})$ and different concentrations of normal dog serum (NDS) on phagocytosis capacity, the yeast cells were incubated with only PBS buffer and with different dilutions of pooled serum; 25, 50, 75 and $100 \%$ serum $(n=6)$. Yeast cells incubated in each solution were phagocytized by granulocytes from the same dog on the same occasion for $25 \mathrm{~min}$. Phagocytic capacity (including active granulocytes, ingested and adhered yeast cells) was increased $(p<0.01)$ by opsonization with $25 \%$ NDS compared with no opsonization at all (Table 2). There was no difference between phagocytosis of yeast, opsonized with the different serum concentrations. A comparative study was conducted between phagocytosis of yeast C3b (50\% serum), yeast $\operatorname{IgG}(0.16 \mathrm{~g} / \mathrm{l})(\mathrm{n}=5)$ and yeast cells opsonized with both serum and IgG. Yeast cells from the different opsonization procedures were incubated for $25 \mathrm{~min}$ with granulocytes from the same dog at the same occasion. No increase in any of our 3 parameters could be demonstrated when opsonizing with IgG compared to NDS. Opsonization with both serum and IgG resulted in an increased acti-

Table 1. Comparison between the number of active granulocytes, ingested and adhered yeast cells at different temperatures $(n=6$ dogs). Values are expressed as mean \pm standard error of the mean.

\begin{tabular}{lccccc}
\hline & $\begin{array}{c}36-37^{\circ} \mathrm{C} \\
\text { mean } \pm \text { s.e.m. }\end{array}$ & p value & $\begin{array}{c}38-39^{\circ} \mathrm{C} \\
\text { mean } \pm \text { s.e.m. }\end{array}$ & p value & $\begin{array}{c}40-41^{\circ} \mathrm{C} \\
\text { mean } \pm \text { s.e.m. }\end{array}$ \\
\hline Active granulocytes & $82 \pm 5.7$ & $\mathrm{~ns}$ & $113 \pm 11$ & $\mathrm{~ns}$ & $83 \pm 11$ \\
Ingested yeast cells & $87 \pm 6.6$ & $\mathrm{~ns}$ & $119 \pm 18$ & $\mathrm{~ns}$ & $103 \pm 22$ \\
Adhered yeast cells & $87 \pm 6.6$ & $\mathrm{~ns}$ & $121 \pm 21$ & $\mathrm{~ns}$ & $111 \pm 20$ \\
\hline
\end{tabular}


Table 2. A comparison between the number of active granulocytes, the number of ingested and adhered yeast cells when opsonized with different concentrations of serum compared to incubation in pure buffer ( $n=6$ dogs). Values are expressed as mean \pm standard error of the mean.

\begin{tabular}{lccccccccc}
\hline & $\begin{array}{c}\text { Buffer } \\
\text { mean } \pm \text { s.e.m. }\end{array}$ & $\mathrm{p}$ value & $\begin{array}{c}25 \% \text { serum } \\
\text { mean } \pm \text { s.e.m. }\end{array}$ & p value & $\begin{array}{c}50 \% \text { serum } \\
\text { mean } \pm \text { s.e.m. }\end{array}$ & p value & $\begin{array}{c}75 \% \text { serum } \\
\text { mean } \pm \text { s.e.m. }\end{array}$ & p value & $\begin{array}{c}100 \% \text { serum } \\
\text { mean } \pm \text { s.e.m. }\end{array}$ \\
\hline $\begin{array}{l}\text { Active } \\
\text { granulocytes }\end{array}$ & $2.6 \pm 1.0$ & $\mathrm{p}<0.01$ & $59 \pm 6.8$ & ns & $68 \pm 2.7$ & ns & $67 \pm 4.3$ & ns & $61 \pm 5.7$ \\
$\begin{array}{l}\text { Ingested } \\
\text { Yeast cells }\end{array}$ & $2.6 \pm 1.0$ & $\mathrm{p}<0.01$ & $127 \pm 27.7$ & ns & $131 \pm 2.5$ & ns & $129 \pm 2.5$ & ns & $119 \pm 27.2$ \\
$\begin{array}{l}\text { Adhered } \\
\text { Yeast cells }\end{array}$ & $0.02 \pm 0$ & $\mathrm{p}<0.01$ & $49 \pm 9.0$ & $\mathrm{~ns}$ & $64 \pm 7.7$ & $\mathrm{~ns}$ & $67 \pm 7.7$ & $\mathrm{~ns}$ & $65 \pm 6.4$ \\
\hline
\end{tabular}

vation and ingestion $(\mathrm{p}<0.05)$ compared with serum opsonization only (Table 3 ).

\section{Study of kinetics}

The number of active granulocytes and the number of serumopsonized ( $50 \%$ serum) ingested and adhered yeast cells were counted after $5,15,25,35$ and 45 min to study the kinetic reaction pattern $(n=31)$.

Granulocytes were incubated with yeast cells in different moistening chambers, one chamber for each incubation period. After each respective time one moistening chamber was taken out and phagocytosis was interrupted. The number of active granulocytes was maximal after $25 \mathrm{~min}$, ingested yeast cells after $35 \mathrm{~min}$ of incubation and adhered yeast cells after $15 \mathrm{~min}$. There was a time dependence of the number of ingested yeast cells $(p<0.001)$ and adhered yeast cells from 5 to $15 \mathrm{~min}(\mathrm{p}<0.001)$ and from 35 to $45 \mathrm{~min}$ $(p<0.05)$. The number of active granulocytes increased with time to $25 \mathrm{~min}(\mathrm{p}<0.001)$ (Fig. 1).

A kinetic study was also conducted on phagocytosis of yeast IgG $(n=12)$. When comparing the kinetics of phagocytosis of yeast IgG with serum opsonized yeast, there was no difference concerning the number of active granulocytes and the number of ingested yeast cells.

\section{Sensitivity of the method}

The error of the method for activated granulocytes was $9.3 \%$ when the 2 readings were on different slides and $10.8 \%$ on the same slide, for ingested yeast cells the error was $10.2 \%(5.7 \%$ on the same slide) and for adhered yeast cells $15.8 \%(14.3 \%)$.

\section{Discussion}

The purpose of this study was to adjust the

Table 3. A comparative study between different opsonins and their effect on the number of active granulocytes, the number of ingested and adhered yeast cells ( $n=5$ dogs). Values are expressed as mean \pm standard error of the mean.

\begin{tabular}{lccccc}
\hline & $\begin{array}{c}\text { Serum } \\
\text { mean } \pm \text { s.e.m. }\end{array}$ & $\mathrm{p}$ value & $\begin{array}{c}\text { Serum } \pm \text { IgG } \\
\text { mean } \pm \text { s.e.m. }\end{array}$ & p value & $\begin{array}{c}\text { IgG } \\
\text { mean } \pm \text { s.e.m. }\end{array}$ \\
\hline Active granulocytes & $53 \pm 3.6$ & $\mathrm{p}<0.05$ & $71 \pm 6.4$ & $\mathrm{~ns}$ & $63 \pm 4.5$ \\
Ingested yeast cells & $57 \pm 6.6$ & $\mathrm{p}<0.05$ & $87 \pm 11.2$ & $\mathrm{~ns}$ & $75 \pm 8.2$ \\
Adhered yeast cells & $35 \pm 4.5$ & $\mathrm{~ns}$ & $37 \pm 4.2$ & $\mathrm{~ns}$ & $36 \pm 9.4$ \\
\hline
\end{tabular}



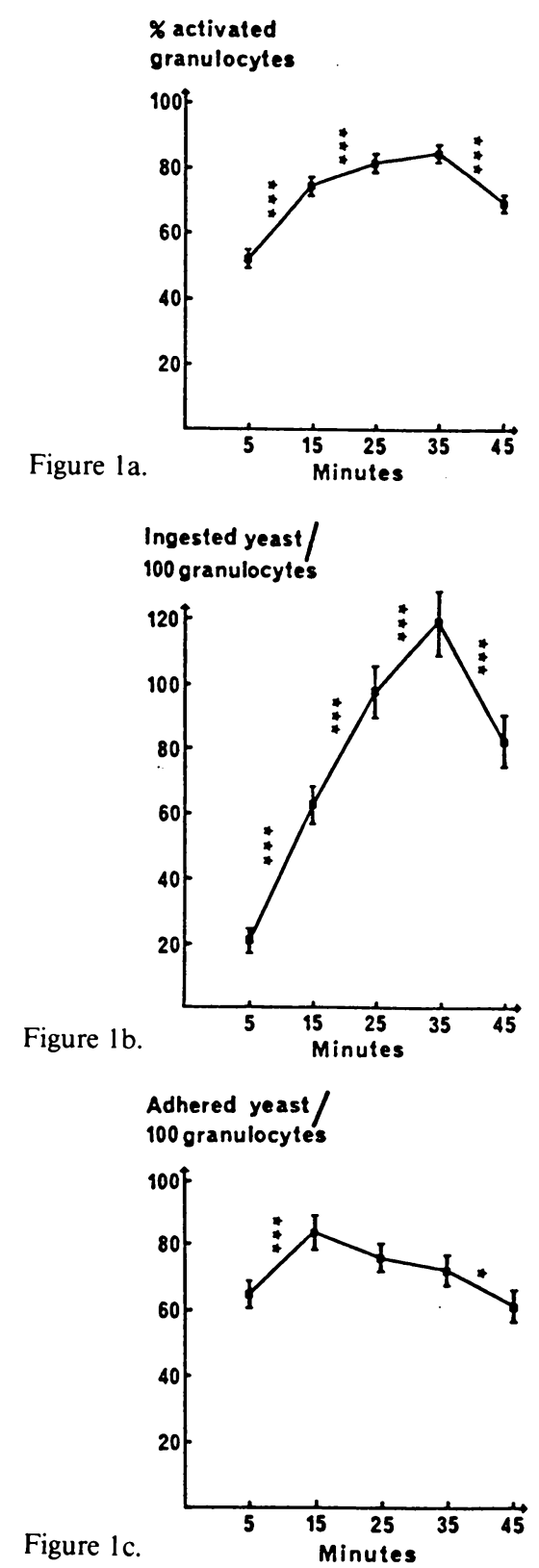

Figure 1. A kinetic study of the number of active (1a) granulocytes, the number of ingested (1b) and adhered (1c) yeast cells at different incubation times $(n=31)$. Values are given as mean \pm s.e.m. method for yeast cell phagocytosis to canine granulocytes and to make clear the influence of temperature, opsonization and time on the number of active granulocytes, and the number of ingested and adhered yeast cells. As mentioned previously the present method for isolating granulocytes yields about $75 \%$ neutrophils. Eosinophils and monocytes can potentially add to the phagocytic effect of the granulocytes. Considering the low number of these cells this additive effect is small. The term granulocyte has been used in this work, as it was not possible to separate neutrophils from other granulocytes when counting the number of active cells.

Elevations in temperature did not changes the number of active granulocytes or ingested and adhered yeast cells in this assay. This confirms the results presented by Mandell (1975) who found that the rate and extent of human phagocytosis were unchanged within a temperature range of 33 to $41^{\circ} \mathrm{C}$. The temperature of $41^{\circ} \mathrm{C}$ is above normal but this did not produce an elevated granulocytic activity in vitro. In vivo, elevated temperature expressed by a febrile process is the results of exogenous pyrogens from antigens which initiate release of endogenous pyrogens from leucocytes (Dinarello, 1979) and also effects several metabolic processes. This may influence the phagocytic activity in the organism and consequentely, a temperature raised above normal on isolated granulocytes in vitro may not reflect the situation in hyperthermic conditions in vivo. Studies on human phagocytic cells have always been conducted at $37^{\circ} \mathrm{C}$ based on the physiological body temperature in man. In dogs the normal body temperature is $38-39^{\circ} \mathrm{C}$ and the following experiments were therefore conducted at that temperature.

The prevalent opsonin in serum for opsonizing Saccharomyces cerevisiae is $\mathrm{C} 3 \mathrm{~b}$, and the yeast particles incubated in NDS were 
therefore supposed to be opsonized with C3b. Hed \& Stendahl (1982) found in their investigations on human granulocytes that C3b molecules decrease the ingestability of yeast cells compared to the non-coated particles while the IgG molecules increased the amount of ingested particles. The effect of $\mathrm{C} 3 \mathrm{~b}$ in this system was to promote attachment while IgG increased the ingestion phase. Our results show that $\mathrm{C} 3 \mathrm{~b}$ opsonization is enough for complete phagocytosis and this is supported by other studies. Capsoni et al. (1977) investigated the role of complement and IgG in the adhesion and ingestion phases of immune complexes by human granulocytes. Even if both types of opsonins are involved in the adhesion phase and IgG primarily in the ingestion phase they found that stimulation with complement is sufficient for complete phagocytosis even if $\mathrm{C} 3$ receptor mediated phagocytosis was less than $\mathrm{Fc}$ receptor mediated. Hällgren \& Stälenheim (1976) studied the uptake of protein A-IgG complexes in human granulocytes and the influence of serum on phagocytosis. They found that serum increased the phagocytosis process and gave a higher maximum uptake.

The best phagocytosis was obtained in our study when yeast cells were incubated with both IgG and serum together. Goldstein et al. (1976) studied the interaction between C3 and IgG on human granulocytes through coating nonphagocytable Sepharose beads with fragments of $\mathrm{C} 3$ and/or IgG. They found that $\mathrm{C} 3$ promotes adherence. This occurs without IgG but could be amplified in the presence of this immunoglobulin. The conclusion in this study was that immunoglobulins and $\mathrm{C} 3 \mathrm{~b}$ indepedently can modulate granulocyte functions.

Hed (1977) reported that human granulocytes should be incubated for $15 \mathrm{~min}$ with yeast cells for optimal phagocytosis. We found that canine granulocytes should be incubated for $35 \mathrm{~min}$ for optimal ingestion in this assay. This difference might be due to species differences in the granulocytes or in opsonizing serum factors. The significant decrease in the number of ingested yeast cells from 35 to $45 \mathrm{~min}$ is probably the result of digestion.

This method of studying phagocytosis is unique as it allows determination of attached and ingested particles of the individual granulocyte. Other methods do not allow this important distinction.

It is also possible to estimate the percent active granulocytes. If granulocytes from 2 individuals show the same amount of ingested yeast cells there can be a considerable difference in the ingestion pattern between them. One of them may have few but very active granulocytes while the remaining are inactive. On the other hand, the other individual may reveal a high amount of active granulocytes but a low consumption per granulocyte. Granulocytes express different types of IgG receptors and they play a role in the binding and ingestion of IgG coated particles. Our method makes it possible, by means of counting the number of active granulocytes, to estimate the proportion of granulocytes expressing Fc receptors. Other authors have shown that it is possible to modulate these receptors, (Petroni et al. 1988, Håkansson et al. 1980) which has important clinical significance.

\section{Acknowledgements}

The authors would like to express a sincere thanks to associated professor Lena Hảkansson for invaluable advice and help and laboratory assistant Ulla Nestor for excellent laboratory assistance. This study was supported by grants from Jordbrukets Försäkringsbolag, Stockholm, Thure F. and Karin Forsbergs Foundation Found and the Swedish Kennelclubs Found for Research. 


\section{References}

Bowles CA, Alsaker RD, Wolfe TL: Study of the Pelger-Hüet anomaly in foxhounds. Am. J. Pathol. 1979, 96, 237-247.

Capsoni F, Caredda F, Borzini P, Lazzarin A: IgG and $\mathrm{C} 3$ receptors on polymorphonuclear leukocytes in phagocytosis. Role of C3-receptors in the attachement and ingestion phases. Boll Ist Sieroter Milan. 1977, 56, 442-448.

Chusid MJ, Bujak JS, Dale DC: Defective polymorphonuclear leucocytes metabolism and function in Canine Cyclic Neutropenia. Blood 1975, 46, 921-930.

Dinarello $C A$ : Production of endogenous pyrogen. Federation proceedings, 1979, 38, 1, 52-56.

Goldstein IM, Kaplan HB, Radin A, Frosch M: Independent effects of $\mathrm{IgG}$ and complement upon human polymorphonuclear leukocyte function. J. Immunol. 1976, 117, 1282-1287.

Gosset KA, Mac Williams S, Enright FM, Cleghorn $B$ : In vitro function of canine neutrophils during experimental inflammatory disease. Vet. Immunol. and Immunopathol. 1984, 5, 151-159.

Hed $J$ : The extinction of fluorescence by chrystal voilet and its use to differentiate between attached and ingested microorganisms in phagocytosis. FEMS Lett. 1977, 1, 357-361.

Hed J, Stendahl O: Differences in the ingestion of IgG and C3 particles in phagocytosis by neutrophils. Immunology, 1982, 45, 727-736.

Holmes B, Page AR, Good RA: Studies of metabolic activity of leucocytes from patients with a genetic abnormality of phagocytic function. The J. of clin. Invest. 1967, 46, 1422-1431.

Hákansson L, Hällgren $R$, Venge P: Effect of hyaluronic acid on phagocytosis of opsonized latex particles. Scand. J. Immun. II, 1980, 649-653.

Hákansson $L$, Venge $P$ : The influence of serum on random migration and chemotaxis of polymorphonuclear leukocytes: Methodological evaluation using sera from infection-prone patients and normals. Scand. J. Immunol. 1980, 11, 271-282.

Hällgren $R$, Stàlenheim $G$ : Quantification of phagocytosis by human neutrophils, the use of radiolabelled staphylococcal protein A-IgG complexes. Immunology, 1976, 30, 755-762.

Hällgren $R$, Jansson $L$, Venge $P$ : Kinetic studies of phagocytosis of IgG-coated latex particles with a thrombocyte counter. J. Lab. clin. Med. 1977, 90, 786-795.

Hällgren $R$, Jansson L, Venge P: Kinetic studies of phagocytosis $\mathrm{I}$. The serum independent particle uptake by PMN from patients with rheumatoid arthritis and systemic lupus erythematosus. Arthritis Rheum. 1978, 21, 107-113.

Hällgren $R$, Fjellström $K-E$, Häkansson L, Venge P: Kinetic studies of phagocytosis II. The serum independent uptake of IgG-coated particles by polymorphonuclear leukocytes from uremic patients on regular dialysis treatment. J. of Lab. and Clin. Med. 1979, 94, 277-284.

Klebanoff SJ, Clark RA: The Neutrophil: function and clincal disorders. North-Holland Publishing Company, Amsterdam 1978, 489-497.

Kroese PGM, Willemse A, Slappendel RJ: Granulocyte function tests in canine infectious diseases: Methods and preliminary clinical results. Vet. Immunol. Immunopathol. 1981, 2, 455-466.

Mandell GL: Effect of temperature on phagocytosis by human polymorphonuclear neutrophils. Infect. Immun. 1975, 12, 221-223.

Morrison WB, Frank DE, Roth IA, Wilsman NJ: Assessment of neutrophil function in dogs with primary ciliary dyskinesia. J. Amer. vet. med. Ass. 1987, 191, 425-430.

Petroni KC, SHen L, Guyre M: Modulation of human polymorphonuclear leucocyte IgG Fc receptors and $\mathrm{Fc}$ receptormediated functions by IFNY and glucocorticoids. J. of Immun. 1988, 140, 3467-3472.

Renshaw HW, Chatburn C, Bryan GM, Bartsch RC, Davis WC: Canine granulocytopathy syndrome: Neutrophil dysfunction in a dog with recurrent infections. Am. J. Vet. Med. Assoc. 1975, 166, 443-447.

Renshaw HW, Davis WC, Renshaw SJ: Canine granulocytopathy syndrome: defective bactericidal capacity of neutrophils from a dog with recurrent infections. Clin. Immunol. Immunopath. 1977, 8, 385-395.

SAS Institute Inc.: SAS User's Guide: Statistics, Version 5 Edition, SAS Institute Inc. Cary, NC. 1985.

Stossel TP: Phagocytosis. N. Engl. J. Med. 1974, 290, 717-723. 


\section{Sammanfattning}

Fagocytos av jästceller; en metodologisk studieavseende hundens granulocyter.

Avsikten med detta arbete har varit att etablera en metod för att mäta förmågan hos hundens neutrofiler att adherera och inkorporera antigen. Denna metod, där isolerade neutrofiler fagocyterar jästceller, tillåter ăven en bedömning av hur stor del av neutrofilpopulationen som är aktiv, dvs antingen har inkorporerat eller adhererat eller båda. Olika faktorers inverkan på de tre parametrarna undersöktes. I temperaturintervallet $36-41^{\circ} \mathrm{C}$ förelåg ej nágon skillnad mellan de olika temperaturerna. Opsonisering med både serum (C3b) och IgG gav en băttre aktivering och inkorporering än opsonisering med bara serum. En kinetisk studie visade att 35 min inkubering gav maximal inkkorporering. På grund av att denna metod ger en så rikhaltig information om individens granulocytfunktion är den mycket lämplig för kliniska ändamål.

(Accepted April 20, 1989).

Reprints may be requested from: Gunilla Trowald-Wigh, Department of Medicine and Surgery, Veterinary Faculty, Swedish University of Agricultural Sciences, P. O. Box 7037, S-750 07 Uppsala, Sweden. 